\title{
Illustrations and Maps
}

Unless otherwise indicated, the illustrations of native artifacts were sketched by Sheila Mitchell Oliver from objects in collections at the Peabody Museum, Harvard University.

Maps of Melanesia, Polynesia, and Micronesia with native navigational chart and art motifs $\quad 1$

Pandanus palm $\quad 3$

Head of club, Marquesas Islands 33

Map of Terra Australis; freely adapted from 1578 map in

E. D. Fite and Archibald Freeman, A Book of Old Maps (Harvard University Press, 1926); original in John Carter Brown Library,

Providence, Rhode Island 35

Carved bowl, megapode and fish, New Britain (author's collection) 46

Figure from Siuai area, Bougainville (author's collection) 60

$\begin{array}{ll}\text { Bougainville club blade } & 76\end{array}$

Carved figure for protection of graves, New Caledonia 85

$\begin{array}{ll}\text { Tapa board, Western Samoa } & 87\end{array}$

Carved wooden figures, New Hebrides $\quad 89$

$\begin{array}{ll}\text { Canoe prow, New Zealand } & 103\end{array}$

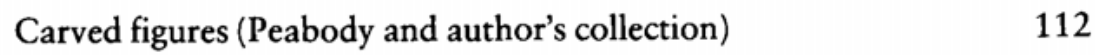

$\begin{array}{ll}\text { Coconut } & 130\end{array}$

$\begin{array}{ll}\text { Pineapple and sugarcane } & 174\end{array}$

$\begin{array}{ll}\text { Fish design, Torres Strait } & 204\end{array}$ 
Seabirds

Clubhouse, Palau Islands

Decoration for bow of canoe, Humboldt Bay area; New Guinea 246

Ceremonial mask, Hawaii

War clubs, Fiji

255

Kit for betel chewing: lime container and spoon, mortar and pestle 268

National god from Rarotonga, Cook Islands

Map 1. Sunda and Sahul

Map 2. Tectonic plates of the Pacific region

Map 3. Ocean currents and surface winds of the Pacific region

Map 4. Rainfall patterns of the Pacific region

Map 5. Ethnic divisions in the Pacific Islands

Map 6. Political divisions in the Pacific Islands in 1939

Map 7. Japan's farthest advances into the Pacific during World War II 